\section{The anonymous probe pDX15 (D15S91) detects an RFLP with Mspl}

X.L.Wen, K.Carland-Saucier, M.Hepburn and M.Rabin* Department of Pediatrics, Division of Genetics, Mailman Center for Child Development, University of Miami, Miami, FL 33101, USA

Source/Description: Probe pDX15 contains a unique $2 \mathrm{~kb}$ human DNA fragment subcloned into the EcoRI site of pBS+ (Stratagene Inc.). This subclone was derived from a $\lambda$ library obtained from Los Alamos National Laboratory (LA15NS03).

Polymorphism: MspI identifies a 2-allele polymorphism:

Al: $5.71 \mathrm{~kb}$

$\mathrm{A} 2: 4.08 \mathrm{~kb}$

Frequency: Estimated from 22 unrelated Caucasians:

A1: 0.82

A2: 0.18

Not Polymorphic For: RsaI, TaqI, BamHI, HindIII, PstI, EcoRI.

Chromosome Localization: Localized to 15q11-q12 using a somatic cell hybrid regional mapping panel (Rich et al., 1988), and by dosage analyses of a panel of chromosome 15-heteroploid cell lines.

Mendelian Inheritance: Co-dominant segregation of the MspI RFLP was observed in three generations of two famiies of 28 individuals

Probe Availability: Contact M.Rabin.

Other Comments: Identifies one allele: TaqI: 3.14 kb; RsaI: 1.89 kb; BamHI: $5.42 \mathrm{~kb}$; HindIII: $2.91 \mathrm{~kb}$; EcoRI: $2.5 \mathrm{~kb}$.

Reference: Rich et al. (1988) Nucl. Acids Res. 16, 8740.

\section{Trinucleotide repeat polymorphism at the human intestinal fatty acid binding protein gene (FABP2)}

Mihael H.Polymeropoulos*, Denise S.Rath, Hong Xiao and Carl R.Merril

National Institute of Mental Health Neuroscience Center, St Elizabeths Hospital, Room 131, 2700 Martin Luther King Avenue, Washington, DC 20032, USA

Source/Description: The polymorphic (TTA) $)_{n}$ repeat begins at base pair 3502 in intron B of the human intestinal fatty acid binding protein gene (FABP2) on chromosome 4q28-q31 (1). The polymorphism can be typed using the polymerase chain reaction (PCR) as described previously (2). The predicted length of the amplified sequence was $113 \mathrm{bp}$.

Primer Sequences: AACTCAGAACAGTGCCTGAC (TTA strand); ATTTCCCTCAAGGCTCCAGGT (AAT strand)

Frequency: Estimated from 50 chromosomes of unrelated individuals. Heterozygosity $=64 \%$.

$\begin{array}{llll}\text { Allele (bp) } & \text { Frequency } & \text { Allele (bp) } & \text { Frequency } \\ \text { A1: } 117 & 0.12 & \text { A4: } 105 & 0.50 \\ \text { A2: } 114 & 0.22 & \text { A5: } 102 & 0.06 \\ \text { A3: } 108 & 0.08 & \text { A6: } 99 & 0.02\end{array}$

Mendelian Inheritance: Co-dominant segregation was observed in two informative families.

Chromosomal Localization: FABP2 gene has been assigned to chromosome 4q28-q31 (1).

Other Comments: The PCR reaction was performed on $80 \mathrm{ng}$ of genomic DNA using 100 pmoles of each oligonucleotide primer. The samples were processed as described (3) except that the denaturation cycle at $94^{\circ} \mathrm{C}$ was extended to 1.4 minutes. The dinucleotide repeat was based on a (TTA) $)_{13}$ sequence.

References: 1) Sweetser,D. et al. (1987) J. Biol. Chem. 262, 16060-16071. 2) Weber,J.L. and May,P.E. (1989) Am. J. Hum. Genet. 44, 388-396. 3) Weber,J.L. et al. (1990) Nucl. Acids Res. 18, 4637. 